\title{
Arminin la-C, a novel antimicrobial peptide from ancient metazoan Hydra, shows potent antileukemia activity against drug-sensitive and drug-resistant leukemia cells
}

This article was published in the following Dove Press journal:

Drug Design, Development and Therapy

\author{
Xiaolei Liang' \\ Ruirui Wang ${ }^{2}$ \\ Wenshan Dou ${ }^{3}$ \\ Li Zhao ${ }^{4}$ \\ Lanxia Zhou ${ }^{4}$ \\ Junfang $\mathrm{Zhu}^{4}$ \\ Kairong Wang ${ }^{5}$ \\ Jiexi Yan ${ }^{4}$
}

'The Reproductive Medicine Special Hospital of the First Hospital of Lanzhou University, Key Laboratory for Reproductive Medicine and Embryo, Lanzhou, China; ${ }^{2}$ The First Clinical Medical College, Lanzhou University, Lanzhou, China; ${ }^{3}$ The Second Clinical Medical College, Lanzhou University, Lanzhou, China;

${ }^{4}$ The Key Laboratory, The First Hospital of Lanzhou University, Lanzhou, China; ${ }^{5}$ School of Basic Medical Sciences, Institute of Biochemistry and Molecular Biology, Lanzhou University, Lanzhou, China

Correspondence: Jiexi Yan

The Key Laboratory, The First Hospital of Lanzhou University, No I, Donggang Road, Lanzhou 730000, China

Tel +869318356820

Email yanjx_II21@I63.com

\begin{abstract}
Purpose: Due to the emergence of multidrug resistance (MDR), traditional antileukemia drugs no longer meet the treatment needs. Therefore, new antileukemia drugs with different action mechanisms are urgently needed to cope with this situation.

Materials and methods: Arminin 1a-C is an antimicrobial peptide (AMP) developed from the ancient metazoan marine Hydra. In this study, we first explored its antileukemia activity. Results: Our results showed that Arminin 1a-C formed an $\alpha$-helical structure and efficaciously suppressed the viability of leukemia cell lines whether or not they were multidrug resistant or sensitive, and there were no obvious differences between these cell lines. Arminin 1a-C exhibited distinct selectivity between noncancerous and cancerous cell lines. Arminin 1a-C interfered with K562/adriamycin (ADM) cell (a kind of multidrug-resistant leukemia cell line) proliferation in a very rapid manner and formed pores in its cell membrane, making it difficult to develop resistance against Arminin 1a-C.
\end{abstract}

Conclusion: Our data show that Arminin 1a-C possesses great potential as a therapeutic candidate for the treatment of multidrug-resistant leukemia.

Keywords: antimicrobial peptide, Arminin 1a-C, antileukemia, multidrug resistance

\section{Introduction}

Despite recent advances in chemotherapy and the use of bone marrow transplantation, a large number of patients with leukemia eventually die of this disease. According to the Cancer Statistics of 2017, approximately 62,000 new leukemia cases were estimated and 24,000 people would die from this disease. ${ }^{1,2}$ As it is difficult to find a suitable donor for bone marrow transplantation, chemotherapy has become an important therapeutic method for most leukemia treatments. However, the multidrug resistance (MDR) of leukemic cells often leads to treatment failure in leukemia patients, which is caused by the extensive use of traditional chemotherapeutic drugs. ${ }^{3}$ In addition, traditional chemotherapeutic agents always cause damage to tissues and healthy cells induced by inadvertent drug interactions, consequently inducing harmful side effects. ${ }^{4,5}$ Therefore, the development of new antileukemia drugs that can prevent the induction of drug resistance and that are not toxic to normal cells has extraordinary significance.

Antimicrobial peptides (AMPs) are expressed in many organisms, and they are diverse in structure. ${ }^{6}$ So far, more than 2,900 cationic AMPs have been purified from nature or chemosynthesized. ${ }^{7}$ AMPs exhibit broad antimicrobial activity against various microbes, 
including bacteria, fungi and viruses. ${ }^{8,9}$ In addition, some of the AMPs play an important role in the innate immune system. ${ }^{10,11}$ In addition to the antimicrobial and immunomodulatory function described earlier, in recent years, the anticancer activity of AMPs has also attracted attention. ${ }^{12,13}$ With the increasing severity of MDR, AMPs may serve as a potential resource for the development of novel anticancer chemotherapy agents, because their mode of action exhibits differences from traditional mechanisms and promises potent activity against a broad spectrum of cancers. ${ }^{14,15}$

The oceans occupy most of the earth's surface and could provide abundant peptides and natural small molecules. Compared with the terrestrial environment, marine organisms live in a totally different environment. They live in an environment filled with microbes that could infect at every opportunity. Therefore, most marine organisms produce AMPs. ${ }^{16}$ Arminin 1a is a novel AMP that was discovered during the investigation of the ancient metazoan Hydra. It did not show any sequence homology to any known AMPs. The C-terminus of Arminin 1a, which consists of 31 amino acids, showed a broad spectrum and potent activity against bacteria, including human multidrug-resistant pathogenic bacteria. ${ }^{17}$

The purpose of the current study includes the following points. First, little is known about the function of Arminin 1a-C besides its antibacterial activity. Therefore, we addressed this problem and explored the antileukemia activity of Arminin 1a-C, especially its activity against drugresistant leukemia cell lines. Second, toxicity of traditional chemotherapeutic drugs still remains the major challenge in the treatment of human malignancies. In this regard, it is meaningful for future clinical applications to research whether the activity of Arminin 1a-C expands to human leukemia cells without causing harm to normal human cells. The third objective was to preliminarily explore the mechanism of Arminin 1a-C action on leukemia cells. An understanding about how Arminin 1a-C kills human leukemia cells might provide a basis for guidance in cancer treatments in the future. Finally, we wanted to confirm the secondary structure of Arminin 1a-C to understand the relationship between its structure and activity. This information is vital to the potential development of Arminin 1a-C as a therapeutic molecule for leukemia.

\section{Materials and methods Peptide}

Arminin 1a-C was synthesized by the $N$-9-fluorenylmethoxycarbonyl (F-moc) stepwise solid-phase method as reported. ${ }^{18}$ LL-37 was obtained from GuoTai Biotechnology (HeFei, China). To preliminarily explore its mechanism of action,
Arminin 1a-C was labeled with fluorescein isothiocyanate (FITC, a fluorescent dye). The FITC-labeled Arminin 1a-C was synthesized following Wender's description. ${ }^{19}$ Homogeneity of these peptides was more than $95 \%$. Electrospray ionization mass spectrometry (ESI-MS) was utilized to evaluate the atomic mass.

\section{Cell lines}

The leukemia cell lines used in this study included the K562 cell line (chronic myelogenous leukemia cell line) and its acquired multidrug-resistant cell line K562/adriamycin (ADM), the HL-60 cell line (promyelocytic leukemia cell line), the THP-1 cell line (monocytic leukemia cell line) and the Jurkat cell line (T cell leukemia cell line). Peripheral blood mononuclear cells (PBMCs), human umbilical vein endothelial cells (HUVECs) and human embryonic kidney cell line (HEK293) were considered noncancerous cells. All the cell lines except PBMCs were obtained from the School of Basic Medical Sciences of Lanzhou University, Lanzhou, China (which were purchased from American Type Culture Collection [ATCC], Manassas, VA, USA). PBMCs were obtained from heparinized blood samples of healthy donors and were isolated using a standard method of Ficoll-Hypaque density-gradient centrifugation (catalog number LTS1077; Haoyang Bioscience, Tianjin, China). ${ }^{20}$ All donors signed an informed consent form, and the experimental protocol was approved by the ethics committee of the First Hospital of Lanzhou University (LDYYLL2017-20). All the cells were cultured in Roswell Park Memorial Institute (RPMI) 1640 medium with $10 \% \mathrm{FBS}$ at $37^{\circ} \mathrm{C}$ in $5 \% \mathrm{CO}_{2}$. The use of cell lines was approved by the institutional review board of the School of Basic Medical Sciences and the First Hospital of Lanzhou University.

\section{Cell proliferation and viability assay}

The cell proliferation and viability activity of Arminin 1a-C against K562/ADM, K562, HL-60, THP-1 and Jurkat cells as well as HUVECs, HEK293 cells and PBMCs were examined by MTT assay as reported. ${ }^{21}$ HUVECs, HEK293 cells and PBMCs were used as normal cells. In brief, $1 \times 10^{4}$ cells/well were seeded in a 96-well plate. Then, Arminin 1a-C (final concentrations were $1.25 \mu \mathrm{M}, 2.5 \mu \mathrm{M}, 5 \mu \mathrm{M}, 10 \mu \mathrm{M}$ and $20 \mu \mathrm{M}$ ) that was dissolved in PBS or PBS alone was added to the wells. Then, 24 hours later, $10 \mu \mathrm{L}$ of $5 \mathrm{mg} / \mathrm{mL}$ MTT (Chemical Abstracts Service [CAS] number: 298-93-1; Beyotime Biotechnology, Shanghai, China) reagent solution was added and incubated for another 4 hours at $37^{\circ} \mathrm{C}$. After that, $100 \mu \mathrm{L}$ of SDS-isobutanol- $\mathrm{HCl}$ solution (10\% SDS, $5 \%$ isobutanol and $12 \mu \mathrm{M} \mathrm{HCl}$ ) was added into each well and 
incubated for 24 hours. Then, the absorbance at $570 \mathrm{~nm}$ was detected by a microplate reader (catalog number: 168-1000; Bio-Rad Laboratories Inc., Hercules, CA, USA).

\section{Hemolytic assay}

The hemolytic activity of Arminin 1a-C was studied according to Ryan et al. ${ }^{22}$ Fresh peripheral blood from healthy volunteers was harvested in heparinized tubes and centrifuged $(800 \times g, 10$ minutes). The pellet was gently washed with cold PBS three times and was resuspended in PBS (erythrocyte working concentration was $8 \%$ ). Then, $100 \mu \mathrm{L}$ of red blood cell suspension was added into a microtiter plate and incubated with $100 \mu \mathrm{L}$ of peptide solution (final concentrations were $10 \mu \mathrm{M}, 25 \mu \mathrm{M}, 50 \mu \mathrm{M}, 75 \mu \mathrm{M}, 100 \mu \mathrm{M}$, $150 \mu \mathrm{M}, 200 \mu \mathrm{M}$ and $300 \mu \mathrm{M})$ for 60 minutes at $37^{\circ} \mathrm{C}$. PBS and Triton-X 100 (0.2\%, CAS number: 9002-93-1; SigmaAldrich Co., St Louis, MO, USA) were considered as negative and positive controls, respectively. Hemoglobin release was measured after centrifugation $(1,000 \times g, 10$ minutes) by a microplate reader at $490 \mathrm{~nm}$.

\section{Lactate dehydrogenase (LDH) detection}

The cytotoxicity of Arminin 1a-C was indicated by LDH leakage into the culture medium. When plasma membranes are injured in cells, LDH release in the media will increase. The released $\mathrm{LDH}$ will reduce $\mathrm{NAD}^{+}$to $\mathrm{NADH}^{+} / \mathrm{H}^{+}$by oxidizing lactate to pyruvate, and two hydrogens are transferred from $\mathrm{NADH}^{+} / \mathrm{H}^{+}$to the yellow tetrazolium salt after an enzymatic reaction..$^{23}$ In this assay, both leukemia cell lines (K562/ADM, K562 and HL-60) and normal cell lines (HUVEC, HEK293 and PBMCs) were assessed. Briefly, cells $\left(1 \times 10^{4} /\right.$ well $)$ were cultured overnight at $37^{\circ} \mathrm{C}$, and then AMPs (final concentrations were $1.25 \mu \mathrm{M}, 2.5 \mu \mathrm{M}, 5 \mu \mathrm{M}$, $10 \mu \mathrm{M}, 20 \mu \mathrm{M}$ and $40 \mu \mathrm{M}$ ) were added and incubated for an additional 4 hours. This test was performed following the manufacturer's instructions (Cytotoxicity Detection Kit ${ }^{\mathrm{PLUS}}$ [LDH], catalog number 04744926001; Hoffman-La Roche Ltd., Basel, Switzerland). After that, the microplate was centrifuged, and then $100 \mu \mathrm{L}$ of medium was transferred to another microplate. LDH reaction mixture was added to each well for a 15-minute reaction. Then, the absorbance at $490 \mathrm{~nm}$ was monitored by a microplate reader (Bio-Rad Laboratories Inc.).

\section{Propidium iodide $(\mathrm{PI})$ uptake assay}

Membrane damage induced by Arminin 1a-C was evaluated by the PI uptake assay. Multidrug-resistant K562/ADM cells were reacted with Arminin 1a-C (final concentration was $10 \mu \mathrm{M}$ ) or PBS only for 30 minutes. After that, a fluorescent dye PI (final concentration was $2 \mu \mathrm{g} / \mathrm{mL}$; CAS number: 25535-16-4; Beyotime Biotechnology) was added and incubated for an additional 10 minutes in the dark at room temperature. Then, cold PBS was added to end the staining and to wash off the excess dye. A fluorescence microscope (TE2000; Nikon Corporation, Tokyo, Japan) was employed to take the fluorescence images.

\section{Scanning electron microscopy (SEM) of K562/ADM}

Approximately $1 \times 10^{6} /$ well K562/ADM cells were seeded in a six-well microplate. Then, $10 \mu \mathrm{M}$ Arminin 1a-C was added for 30 minutes. The cells were harvested and washed gently with PBS. Then, $1 \mathrm{~mL}$ of $3 \%$ glutaraldehyde solution was used to fix the cells. After cell fixation, all pellets were impregnated in $2.5 \%$ tannic acid for 2 days, and then they were counter fixed in $2 \%$ osmium tetroxide for 2 hours. Following dehydration in ethanol, the cells were dried in a freeze-drying device (JEOL-JFD-310; JEOL, Tokyo, Japan) and coated with gold. SEM (JSM-6380Lv; JEOL Ltd., Tokyo, Japan) was used to compare the membrane alterations.

\section{Flow cytometry analysis}

The membrane permeability of the peptide was monitored by flow cytometry analysis by FITC-labeled Arminin 1a-C. In brief, K562/ADM cells were washed three times with PBS and were resuspended to obtain a $10^{6} / \mathrm{mL}$ cell suspension. Then, $0.25 \mathrm{~mL}$ of Arminin 1a-C (final concentrations were $1.25 \mu \mathrm{M}$, $2.5 \mu \mathrm{M}, 5 \mu \mathrm{M}, 10 \mu \mathrm{M}$ and $20 \mu \mathrm{M}$ ) was incubated with $0.25 \mathrm{~mL}$ of cell suspension for 15 minutes. A flow cytometer (Beckman Coulter, Inc., Brea, CA, USA) was utilized to obtain data, which were analyzed by CellQuest Pro software.

\section{Circular dichroism (CD) spectrum}

The secondary structure of Arminin 1a-C was analyzed by CD spectra using an Olis DSM 1000 CD spectrophotometer (Olis, Inc., Augusta, GA, USA) according to a previously reported protocol. ${ }^{24}$ The spectrophotometer was operated under a nitrogen flush with a $1 \mathrm{~mm}$ path length at room temperature. Arminin 1a-C was dissolved in trifluoroethanol (TFE; 50\%, v/v, CAS number: 75-89-8; Sigma-Aldrich Co.) or $10 \mathrm{mM}$ PBS (final concentration was $50 \mu \mathrm{M}$ ). Then, the spectra of these solutions were recorded between $195 \mathrm{~nm}$ and $240 \mathrm{~nm}$ using a quartz cuvette. The percentage of $\alpha$-helical structure content was calculated according to the following formula:

$$
f_{H}=\frac{\Theta_{222}^{o b s}-\Theta_{222}^{C}}{\Theta_{222}^{H}-\Theta_{222}^{C}}
$$


where $\Theta_{222}^{C}(=+640)$ is the complete random coil ellipticity. $\Theta_{222}^{H}$ is the mean ellipticity for complete helical conformation and is given by

$$
\Theta_{222}^{H}=-42,500\left(\frac{1-x}{n}\right)
$$

where $n$ is the chain length in residues and $x$ is the number of non-H-bonded carbonyl groups in the peptides. For carboxyamidated peptides, Rohl and Baldwin ${ }^{25}$ proposed that $x=3$.

\section{Results}

\section{Peptides}

Arminin 1a-C is composed of 31 amino acids, and the primary sequence and other biophysical parameters are summarized in Table 1. The HPLC chromatogram and MS are shown in Figures $\mathrm{S} 1$ and $\mathrm{S} 2$, respectively. The peptide contains a series of lysine and arginine residues located at different positions. Lysine, arginine and the N-terminus were considered to be positive charges. The $\mathrm{C}$-terminus of this peptide is amidated, which makes Arminin 1a-C confer a charge of +13 together with other positive amino acids. The detailed biophysical property predictions of Arminin 1a-C were determined based on Srivastava and Ghosh ${ }^{26}$ The mean hydrophobicity $(\mathrm{H})$ and hydrophobic moment of the peptide were calculated utilizing the consensus scale of hydrophobicity stated by Eisenberg and Mclachlan. ${ }^{27}$ The secondary structure of Arminin 1a-C was predicted by the software supplied by the web. The website is http://heliquest.ipmc.cnrs.fr/, and it showed that Arminin 1a-C adopted an $\alpha$-helix structure according to the prediction software (Figure 1). ${ }^{28}$

\section{Cell proliferation inhibition activity of Arminin Ia-C against different cells}

The proliferation inhibition activity of Arminin 1a-C against a panel of leukemia cells as well as normal cell lines was detected by the MTT assay. The results showed that Arminin 1a-C exhibited proliferation inhibition activity against a wide range of leukemia cell lines (Figure 2). The multidrug- resistant phenotype is not expressed in K562 cells, but it is overexpressed in K562/ADM cells, which is reflected by the different expression levels of P-glycoprotein (P-gp) in K562/ $\mathrm{ADM}$ and $\mathrm{K} 562$ cells, respectively (Figure S3). As shown in Figure 1, both the proliferation of K562 and its drug-resistant cell line K562/ADM were inhibited by Arminin 1a-C. For other different leukemia cell lines, Arminin 1a-C also showed significant suppressive activity despite some differences in degrees between cell lines. All the proliferation inhibition activity occurred in a peptide concentration-dependent manner. For the normal cell lines, although Arminin 1a-C also exhibited a minor inhibition effect, the $\mathrm{IC}_{50}$ values of the normal cell lines were higher than the $\mathrm{IC}_{50}$ values of leukemia cell lines (Table 2). These results indicated that Arminin 1a-C may be considered as an efficient candidate against leukemia cells whether they were multidrug resistant or not, and they indicated selectivity between normal cells and leukemia cells.

\section{Arminin Ia-C showed negligible hemolytic activity against human erythrocytes}

The cell selectivity of this peptide was checked by human erythrocyte lysis. As shown in Figure 3, although Arminin 1a-C displayed antileukemia activity at the concentration of $10 \mu \mathrm{M}$, it did not show any apparent hemolytic activity at this concentration. Even at concentrations up to $300 \mu \mathrm{M}$, only $15 \%$ lysis was observed. Therefore, the hemolytic activity may be negligible at its effective concentration. In comparison, LL-37, a well-studied AMP, ${ }^{29}$ showed approximately $35 \%$ hemolysis at the concentration of $300 \mu \mathrm{M}$. This result indicated that Arminin 1a-C showed specific cytotoxicity for leukemia cells relative to normal human erythrocytes.

\section{Cytotoxicity of Arminin Ia-C against different cell lines}

Potential cytotoxicity effects of Arminin $1 \mathrm{a}-\mathrm{C}$ were also examined by assessing the activity of the cytoplasmic enzyme

Table I Amino acid sequence, molecular weight and biophysical parameters of Arminin Ia-C

\begin{tabular}{|c|c|c|c|c|c|c|c|c|}
\hline \multirow[t]{2}{*}{ Peptide } & \multirow[t]{2}{*}{ Sequence } & \multirow{2}{*}{$\begin{array}{l}\text { Length } \\
\text { (a.a) }\end{array}$} & \multicolumn{2}{|l|}{ MW } & \multirow{2}{*}{$\begin{array}{l}\text { Net } \\
\text { charge }\end{array}$} & \multirow[t]{2}{*}{$\mathbf{p l}^{\mathbf{a}}$} & \multirow{2}{*}{$\begin{array}{l}\text { Hydrophobicity } \\
\text { (H) }\end{array}$} & \multirow{2}{*}{$\begin{array}{l}\text { Hydrophobic } \\
\text { moment }^{\text {b }} \\
(\mu \mathrm{H})\end{array}$} \\
\hline & & & M.cal $^{\mathbf{a}}$ & M.obs & & & & \\
\hline $\begin{array}{l}\text { Arminin } \\
\text { la-C }\end{array}$ & $\begin{array}{l}\text { KPWRFRRAIRRVRWRKVAPYIPFVVKTVGKK- } \\
\mathrm{NH}_{2}\end{array}$ & 31 & $3,895.8$ & $3,896.6$ & 13 & $|2.4|$ & 0.315 & 0.205 \\
\hline
\end{tabular}

Notes: a Molecular weight was calculated, and the isoelectric point (pl) of Arminin la-C was estimated by http://web.expasy.org/compute_pil. ${ }^{\mathrm{b}}$ The mean hydrophobicity and hydrophobic moment $(\mu \mathrm{H})$ of Arminin Ia-C were calculated using the consensus scale of hydrophobicity proposed by Eisenberg and Mclachlan. ${ }^{27}$

Abbreviations: a.a, amino acid; M.cal, molecular weight calculated; M.obs, molecular weight observed; MW, molecular weight. 


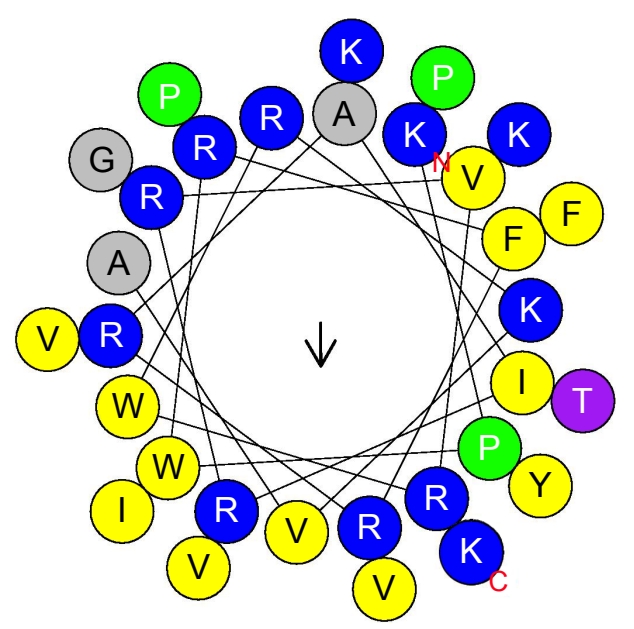

Figure I Helical wheel projection of Arminin Ia-C.

Notes: The secondary structure of Arminin Ia-C was predicted by the website (http://heliquest.ipmc.cnrs.fr/). The red $\mathrm{N}$ represents $\mathrm{N}$-terminal of the peptide sequence. The red $\mathrm{C}$ represent the $\mathrm{C}$-terminal of the peptide sequence.

LDH in the culture medium of peptide-treated cells. According to the LDH assay, Arminin 1a-C caused a concentrationdependent increase in LDH release in the tested leukemia cell lines. By contrast, normal cell lines showed apparently much lower LDH release. As shown in Figure 4, significant differences were observed between the leukemia cell lines and the normal cell lines tested. This result was consistent with the hemolytic assay conducted previously, confirming the selective antileukemia activities of Arminin 1a-C.

\section{Arminin Ia-C induced PI permeation by disturbing multidrug-resistant leukemia cell membrane}

As we know that PI is a fluorescent dye that can penetrate into cells, intercalate with their DNA and make the cells red

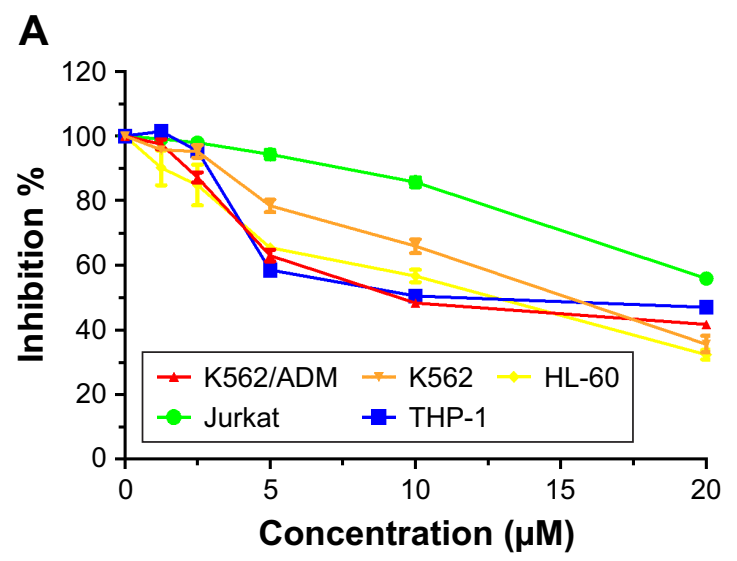

when they die or when their membranes are compromised. ${ }^{30}$ The K562/ADM cell lines were incubated with Arminin 1a-C and then were stained with PI. Most K562/ADM cells treated with Arminin 1a-C turned to red, while the cells treated only with PBS did not show any fluorescence (Figure 5). These results showed that Arminin 1a-C disturbed the multidrugresistant leukemia cell membrane, which led to PI passing through the membrane and binding to DNA.

\section{Membrane morphological alterations induced by Arminin Ia-C}

We speculated that Arminin 1a-C disturbed the multidrugresistant leukemia cell membrane according to the PI uptake assay results. To give a more intuitive visualization, SEM was used to observe the effect of Arminin 1a-C on K562/ADM cell membranes. After treatment with $10 \mu \mathrm{M}$ Arminin 1a-C, remarkable differences in the morphology between untreated and treated leukemia cells were discovered. As shown in Figure 5, untreated leukemia cells displayed a regular smooth surface, and cells were integrated (Figure 6A-C); however, the treated leukemia cells presented a cell membrane that was destroyed by pore formation (Figure 6D-F).

\section{Flow cytometry}

To evaluate the affinity of Arminin 1a-C with multidrugresistant leukemia cells, Arminin 1a-C was labeled with the fluorescent dye FITC and was analyzed by flow cytometry. Flow cytometry revealed a significant fluorescence shifting when K562/ADM cells were treated with different concentrations of FITC-labeled Arminin 1a-C (Figure 7). This result demonstrated that Arminin 1a-c showed a strong affinity with

\section{B}

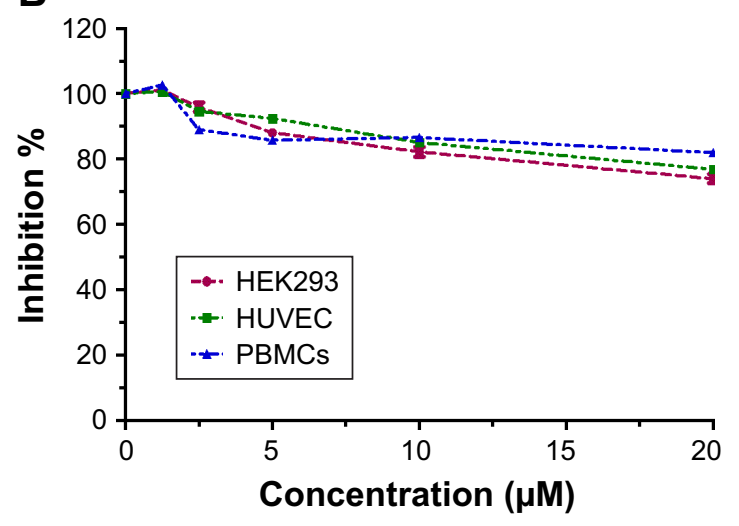

Figure 2 Proliferation inhibition effects of Arminin Ia-C on leukemia cell lines and normal cell lines.

Notes: Cells were incubated with Arminin la-C (final concentrations were I.25 $\mu$ M, $2.5 \mu \mathrm{M}, 5 \mu \mathrm{M}, 10 \mu \mathrm{M}$ and $20 \mu \mathrm{M}$ ) for 24 hours, and then the MTT assay was conducted. Error bars represent mean \pm SEM determined by three independent experiments. (A) Leukemia cell lines; (B) normal cell lines.

Abbreviations: ADM, adriamycin; HEK293, human embryonic kidney cell line; HUVECs, human umbilical vein endothelial cells; PBMCs, peripheral blood mononuclear cells; SEM, standard error of the mean. 
Table 2 In vitro anti-proliferation activity of Arminin Ia-C against different leukemia cell lines and normal cell lines

\begin{tabular}{|c|c|c|c|c|c|c|c|c|}
\hline \multirow{2}{*}{$\begin{array}{l}\text { Cell proliferation assay, } \\
\mathrm{IC}_{50}(\mu \mathrm{M})\end{array}$} & \multicolumn{8}{|l|}{ Cell lines } \\
\hline & K562/ADM & K562 & HL-60 & THP-I & Jurkat & HUVEC & HEK293 & PBMCs \\
\hline Arminin $\mathrm{Ia}-\mathrm{C}$ & 14.10 & 17.20 & II.48 & 17.13 & 32.19 & 61.02 & 50.58 & 275.4 \\
\hline
\end{tabular}

Notes: ${ }^{a} C_{50}$ : peptide concentration at which cell viability was reduced to $50 \%$ compared with untreated cells.

Abbreviations: ADM, adriamycin; HEK293, human embryonic kidney cell line; HUVECs, human umbilical vein endothelial cells; PBMCs, peripheral blood mononuclear cells.

the cell membrane of multidrug-resistant cells, and this effect was concentration dependent with the peptide concentration increment. Meanwhile, the binding process occurred very quickly and was almost complete in a few minutes.

\section{Secondary structure analysis of Arminin Ia-C}

As mentioned earlier, we predicted the secondary structure of Arminin 1a-C using a prediction software program, and it showed that Arminin 1a-C adopted an $\alpha$-helix structure. To verify the accuracy of this prediction, CD spectroscopy was used to analyze the secondary structure of Arminin 1a-C. We analyzed the secondary structures of this peptide in two absolutely different environments: one was in PBS (to mimic a benign condition) and the other was in $50 \%$ TFE (mimicking the hydrophobic environment of the membrane). Our data exhibited that, in the benign condition, Arminin 1a-C adopted a typical random coil structure (Figure 8). In contrast, it exhibited two negative bands at $208 \mathrm{~nm}$ and $222 \mathrm{~nm}$ in 50\% TFE. These results indicated that Arminin 1a-C took a typical $\alpha$-helical structure in the

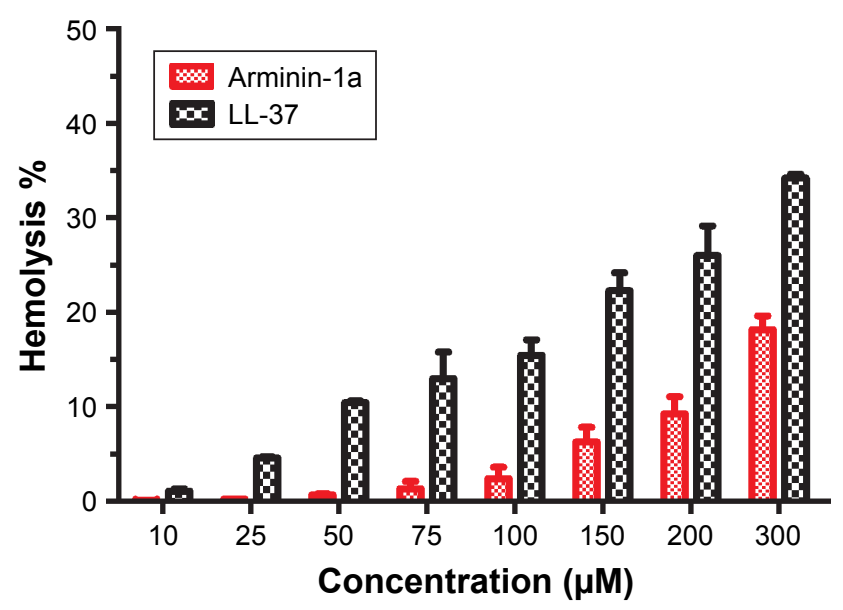

Figure 3 The hemolytic activity of Arminin Ia-C was investigated by hemoglobin release assay. Fresh human erythrocyte suspension $(100 \mu \mathrm{L})$ was incubated with Arminin Ia-C and LL-37 (final concentrations were $10 \mu \mathrm{M}, 25 \mu \mathrm{M}, 50 \mu \mathrm{M}, 75 \mu \mathrm{M}$, $100 \mu \mathrm{M}, 150 \mu \mathrm{M}, 200 \mu \mathrm{M}, 300 \mu \mathrm{M})$ for 60 minutes at $37^{\circ} \mathrm{C}$.

Notes: Hemoglobin release was measured after centrifugation ( $1,000 \times \mathrm{g}, 10$ minutes) by a microplate reader at $490 \mathrm{~nm}$. PBS and $0.2 \%$ Triton-X I 00 were used as negative and positive controls, respectively. membrane-mimicking environment, just as the prediction. Meanwhile, the $\alpha$-helix contents of Arminin 1a-C in these two different environments were calculated and are summarized in Table 3.

\section{Discussion}

With the recent developments in treatment strategies, complete remission of leukemia can be induced up to $60 \%-80 \%$ of new cases. However, a large proportion of patients still eventually die of this disease, and one of the most important reasons is the emergence of MDR. ${ }^{31}$ Under this background, new antileukemia drugs with different action mechanisms are urgently needed to cope with this problem. In this study, we investigated the in vitro activity of Arminin 1a-C, a novel AMP from ancient metazoan Hydra, against several leukemia cell lines, including both multidrug-sensitive and multidrug-resistant cell lines. The mechanism of its antileukemia activity was also preliminarily studied.

Previous studies have shown that the mechanisms of gradual development of cancer cell resistance to chemotherapy involve altered interactions between the drug and its target, enhancement of the DNA damage repair ability, increment of drug transporters or drug detoxifying enzymes expression, and attenuation in the cellular machinery that mediates apoptosis. ${ }^{32,33}$ For example, the most studied MDR mechanisms are induced by the expression of a $170 \mathrm{kDa}$ membrane glycoprotein (P-gp) that normally acts as a drugefflux pump. ${ }^{34}$ Therefore, in this study, we first detected the P-gp expression between K562 and K562/ADM as given in the "Supplementary materials" section and found that P-gp was highly expressed in K562/ADM cells (Figure S3), and then we performed the following experiments. ADM, a traditional chemotherapy agent utilized to treat tumors (such as acute lymphocytic leukemia, lymphoma and breast cancer), has an $\mathrm{IC}_{50}$ against K562 cells and K562/ADM cells of $14 \mathrm{nM}$ and 2,820 nM, respectively. ${ }^{35} \mathrm{In}$ contrast, our results showed that the $\mathrm{IC}_{50}$ of Arminin 1a-C against K562 cells and K562/ ADM cells was $17.20 \mu \mathrm{M}$ and $14.10 \mu \mathrm{M}$, respectively. Arminin 1a-C not only inhibited the growth of multidrug-sensitive 

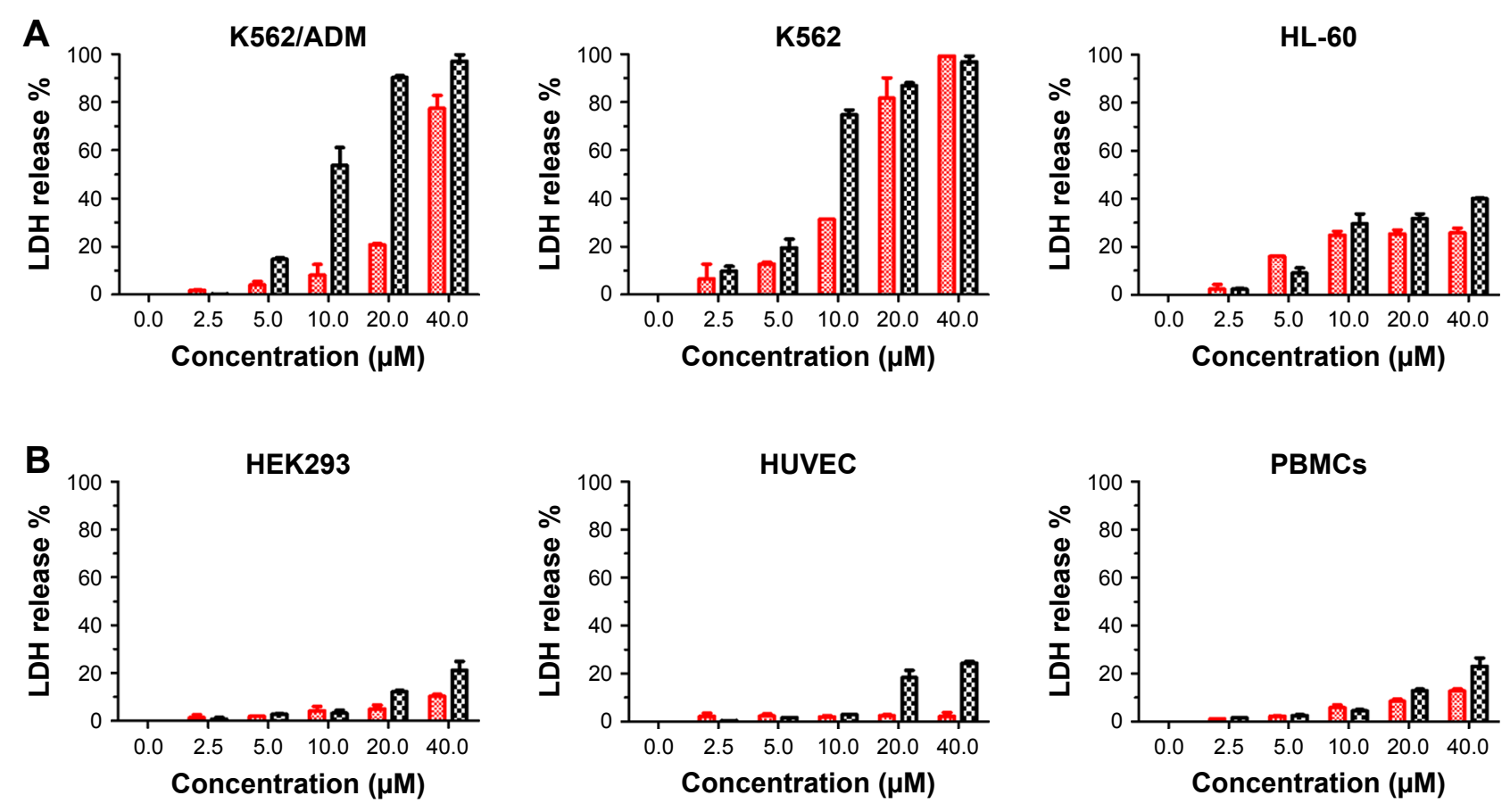

Figure $\mathbf{4}$ Cytotoxicity effects of Arminin la-C on leukemia cell lines and normal cell lines.

Notes: Cells were treated with Arminin Ia-C and LL-37 (final concentrations were $1.25 \mu \mathrm{M}, 2.5 \mu \mathrm{M}, 5 \mu \mathrm{M}, 10 \mu \mathrm{M}, 20 \mu \mathrm{M}$ and $40 \mu \mathrm{M}$ ) for 4 hours. Then, $100 \mu \mathrm{L}$ of the cell culture supernatant was transferred to another microplate after centrifugation. After a 15-minute reaction with the LDH reaction mixture, the absorbances at $490 \mathrm{~nm}$ were recorded. (A) leukemia cell lines and (B) represents normal cell lines.

Abbreviations: ADM, adriamycin; HEK293, human embryonic kidney cell line; HUVECs, human umbilical vein endothelial cells; LDH, lactate dehydrogenase; PBMCs, peripheral blood mononuclear cells.
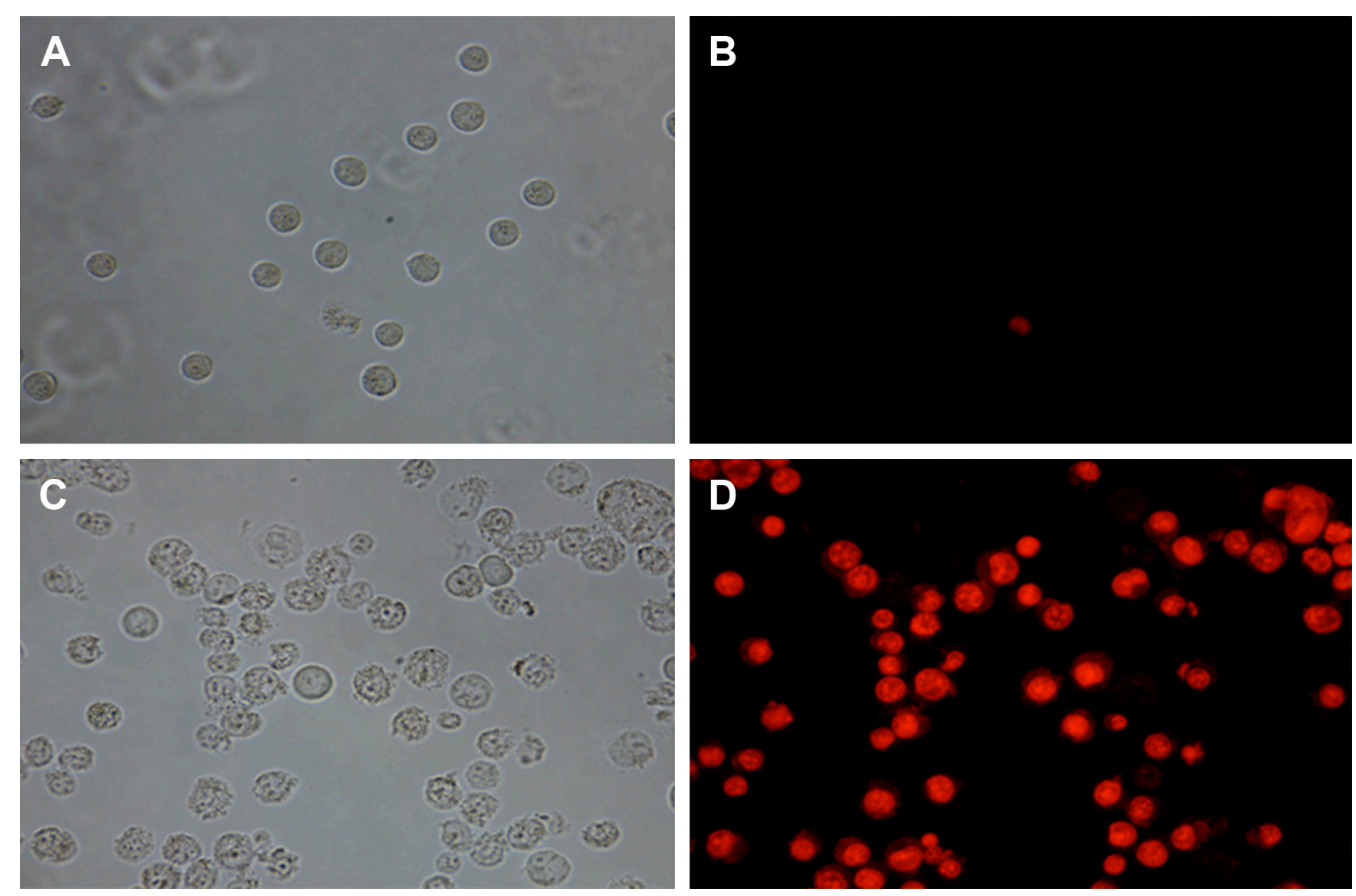

Figure 5 Arminin Ia-C induced fluorescent dye PI permeation by disturbing multidrug-resistant leukemia cell membranes.

Notes: Multidrug-resistant K562/ADM cells were treated with $10 \mu$ M Arminin la-C or PBS alone for 30 minutes. PI dye was added to the cells for 10 minutes in the dark at room temperature. After washing the excessive dye, fluorescence images were taken by a fluorescence microscope. (A, B) K562/ADM cells were incubated with PBS alone. (C, D) K562/ADM cells were incubated with Arminin Ia-C.

Abbreviations: ADM, adriamycin; PI, propidium iodide. 

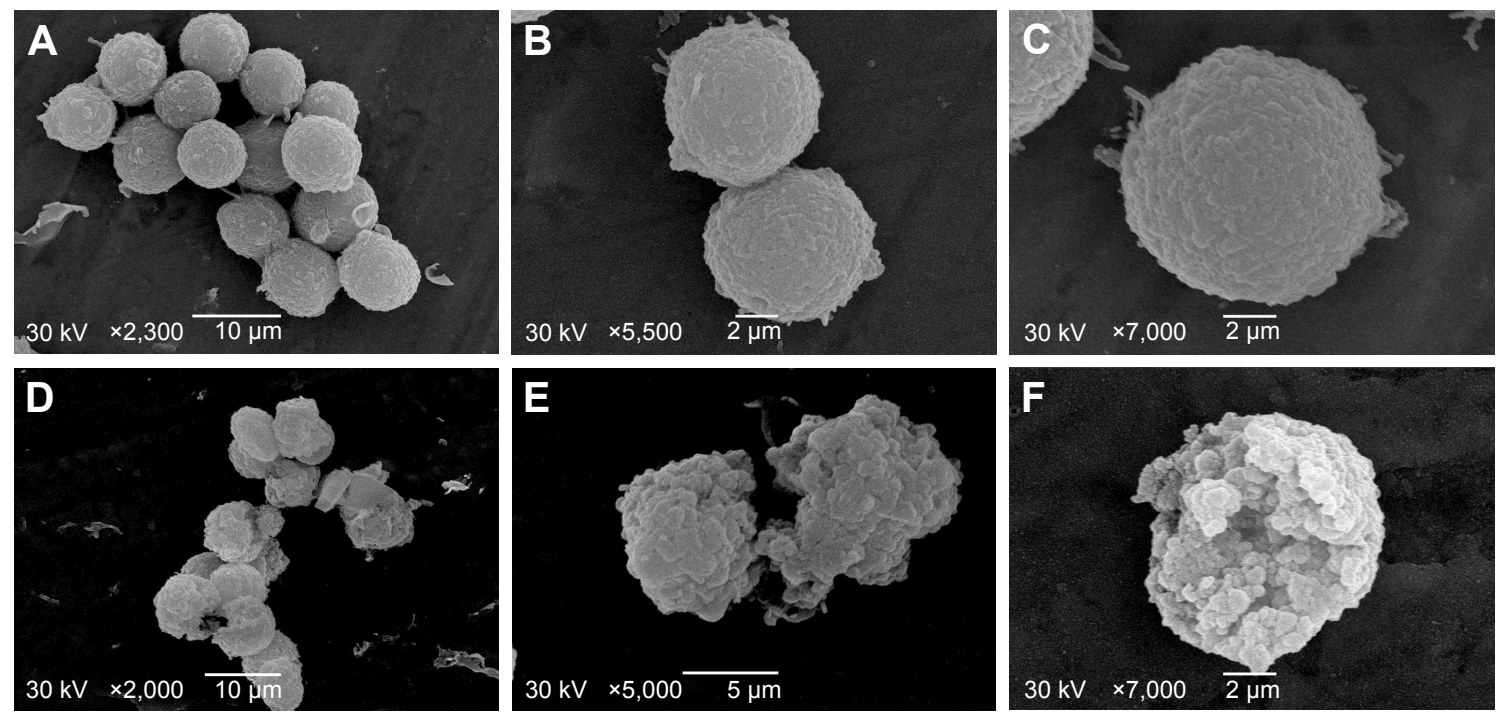

Figure 6 Morphological alteration of K562/ADM cell membranes after Arminin Ia-C treatment.

Notes: K562/ADM cells were treated with PBS or $10 \mu \mathrm{M}$ of Arminin la-C for 30 minutes. Then, the cells were harvested and prepared to undergo SEM, which was used to compare the membrane alterations. (A-C) K562/ADM cells were incubated with PBS alone. (D-F) K562/ADM cells were incubated with $10 \mu M$ of Arminin Ia-C for 30 minutes.

Abbreviations: ADM, adriamycin; SEM, scanning electron microscopy.

but also multidrug-resistant leukemia cells. It showed similar (LDH assay) or even better anti-proliferation activity (MTT assay) against K562/ADM cells compared with the sensitive leukemia cell lines, which suggested that this peptide was not affected by the P-gp-related mechanism of resistance. Moreover, Arminin 1a-C also exhibited obvious selectivity between noncancerous cells and the leukemia cells. LL-37 was the most studied AMP in host defense. Our previous study showed that LL-37 also had proliferation inhibition activity against leukemia cell lines. ${ }^{21}$ Its antileukemia activity was comparable with that of Arminin 1a-C. While its IC50 against PBMCs was $16.97 \mu \mathrm{M}$, which is much lower than that of Arminin 1a-C. Meanwhile, the hemolytic activity and cytotoxicity of LL-37 against noncancerous cells were higher than those of Arminin 1a-C, which are very important evaluation factors for potential anticancer agents. Taking all of these results into consideration, we speculated that the regular mechanism of P-gp-related resistance would not impact the action of Arminin 1a-C. It will be outstanding in the treatment of multidrug-resistant leukemia when compared with traditional chemotherapy drugs.

P-gp transports endogenous phosphatidylserine (PS) to the outer leaflet of the cell membrane among a variety of substrates. This transport may contribute to the net negative

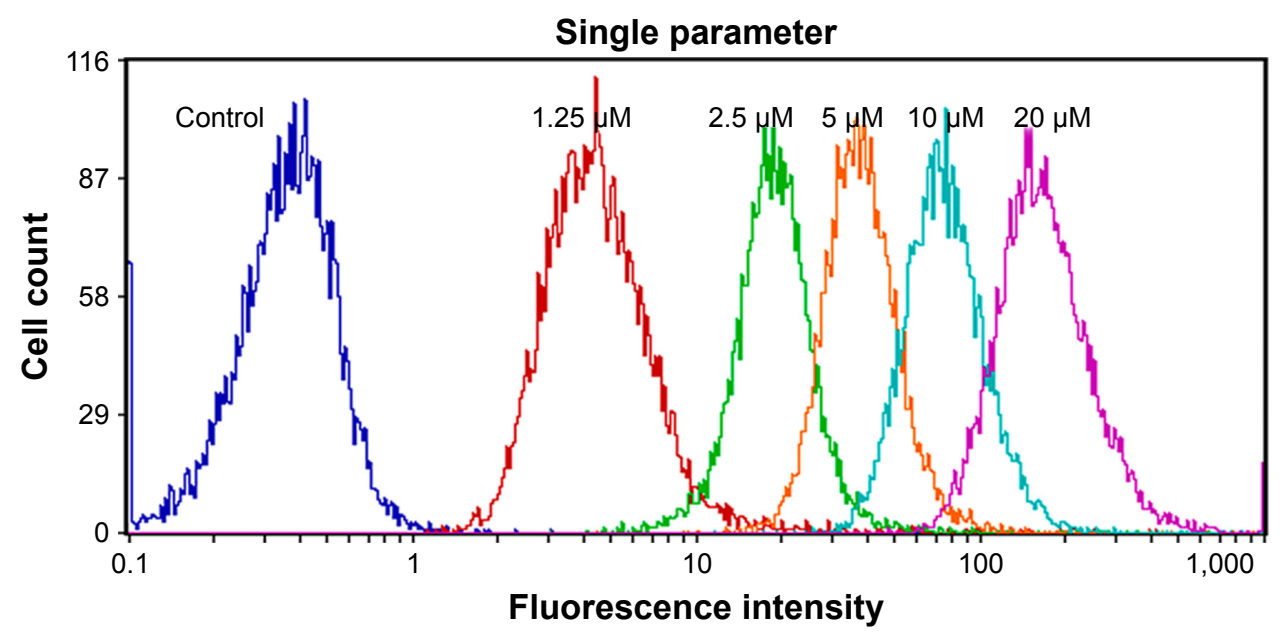

Figure 7 Affinity of Arminin Ia-C with multidrug-resistant cells. $10^{6} / \mathrm{mL} \mathrm{K562/ADM}$ cells were treated with FITC-labeled Arminin Ia-C for I5 minutes at $37^{\circ} \mathrm{C}$ in the dark. Then, a flow cytometer was utilized to monitor the fluorescence alteration.

Abbreviations: ADM, adriamycin; FITC, fluorescein isothiocyanate. 


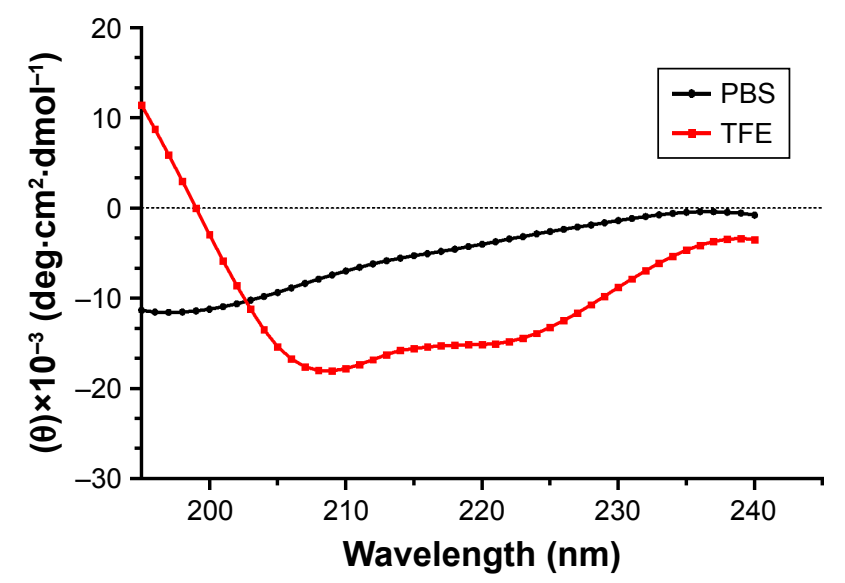

Figure $\mathbf{8}$ The secondary structure of Arminin Ia-C in different environments was analyzed by $C D$ spectra.

Notes: Arminin Ia-C $(50 \mu \mathrm{M})$ was dissolved in $10 \mathrm{mM}$ PBS or $50 \%$ TFE, respectively. PBS was used to mimic a benign condition, and $50 \%$ TFE was used to mimic the hydrophobic environment of the membrane.

Abbreviations: $C D$, circular dichroism; TFE, trifluoroethanol.

charge of the cell membrane. ${ }^{34}$ According to the references, cancer cells consist of comparatively more PS in the outer leaflet of the membrane.$^{35}$ In contrast, noncancerous plasma membranes do not have this characteristic. ${ }^{36,37}$ Therefore, increased exposure of negatively charged PS is one of the main differences between cancerous and noncancerous cells. This result has been demonstrated in our previous research. It showed that K562 and its resistant cell line K562/ADM express a much higher level of PS. ${ }^{38}$ This might be the reason why positively charged Arminin 1a-C not only showed higher inhibition activity against K562/ADM cells but also showed selectivity between leukemia and normal cells. Most of the currently used clinical antitumor chemotherapies show not only antitumor activity but also severe side effects. Compared with this, a main advantage of Arminin 1a-C is its cellular selectivity for leukemia cells. Therefore, it is expected to be an excellent candidate as a novel effective antileukemia agent that shows selective cytotoxicity.

To date, most of the studied AMPs would disturb or interact with the target cell membrane, inducing cell death., ${ }^{439,40}$ It is not easy for tumor cells to develop resistance against

Table 3 CD data of Arminin Ia-C in different environments

\begin{tabular}{|l|l|l|l|l|}
\hline \multirow{2}{*}{ Peptide } & \multicolumn{2}{|l|}{10 mM PBS $^{\mathrm{a}}$} & \multicolumn{2}{l|}{${\text { 50\% } \text { TFE }^{\mathrm{b}}}$} \\
\cline { 2 - 5 } & $(\boldsymbol{\theta})_{222}$ & $\alpha$-helix (\%) & $\mathbf{(}\left(\boldsymbol{) _ { 2 2 2 }}\right.$ & $\alpha$-helix (\%) \\
\hline Arminin Ia-C & $-3,439.89$ & 10.45399 & $-14,806.6$ & 39.57917 \\
\hline
\end{tabular}

Notes: aThe mean residue molar ellipticity (degree $\mathrm{cm}^{2} \mathrm{dmol}^{-1}$ ) at the wavelength of $222 \mathrm{~nm}$ was measured at room temperature in $10 \mathrm{mM}$ PBS, pH 7.4. ${ }^{\circ}$ The mean residue molar ellipticity (degree $\mathrm{cm}^{2} \mathrm{dmol}^{-1}$ ) at the wavelength of $222 \mathrm{~nm}$ was measured at room temperature in PBS diluted I:I (v/v) with TFE. 'The percentage of $\alpha$-helical contents of the peptide was calculated by using the formula provided from Rohl and Baldwin. ${ }^{25}$

Abbreviations: $C D$, circular dichroism; TFE, trifluoroethanol.
AMPs since these processes need a total change of the cell membrane, which is related to multiple biochemical pathways and signaling pathways. ${ }^{33,41}$ Our results showed that Arminin 1a-C interacts with multidrug-resistant K562/ $\mathrm{ADM}$ cells in a very rapid manner to form pores in the cell membrane. This process might induce the cytoplasm of K562/ADM leakage and finally cause death. Because this whole process happened in a few minutes, we speculated that it is difficult for K562/ADM cells to develop resistance against Arminin 1a-C.

\section{Conclusion}

We have first shown that the marine-derived $\alpha$-helical AMP Arminin $1 \mathrm{a}-\mathrm{C}$ exhibited growth inhibitory activity against different human leukemia cells regardless of whether it was multidrug resistant or not. Moreover, it did not have any obvious adverse effects on the viability of normal human cells and exhibited selectivity between noncancerous and cancerous cells. Arminin 1a-C acted quickly to disrupt the membrane of multidrug-resistant leukemia cells and formed pores in it. This process was finished in minutes, indicating that it was not easy for K562/ADM cells to develop resistance. All this information demonstrated that Arminin 1a-C possesses great potential and needs further studies to define its possible role as a therapeutic molecule in treatment of leukemia to counteract the MDR phenomenon.

\section{Acknowledgment}

This study was supported by the National Natural Science Foundation of China (No: 81601351), the Fundamental Research Funds for the Central Universities (lzujbky2017-82), the Science Foundation of the Gansu Province, China (Nos: 1606RJZA133, 17JR5RA267, 1308RJZA139) and the Science and Technology plan of Chengguan District of Lanzhou City (2017KJGG0014).

\section{Author contributions}

Xiaolei Liang and Jiexi Yan conceived and designed the experiments and wrote the paper. Ruirui Wang, Wenshan Dou, Junfang Zhu, Li Zhao and Lanxia Zhou performed the experiments. Kairong Wang revised and edited the manuscript. All authors contributed toward data analysis, drafting and revising the paper and agree to be accountable for all aspects of the work.

\section{Disclosure}

The authors report no conflicts of interest in this work. 


\section{References}

1. Howlader NNA, Krapcho M, Miller D. SEER Cancer Statistics Review, 1975-2014. National Cancer Institute; 2017.

2. Siegel RL, Miller KD, Fedewa SA, et al. Colorectal cancer statistics, 2017. CA Cancer J Clin. 2017;67(3):177-193.

3. Singh MS, Tammam SN, Shetab Boushehri MA, Lamprecht A. MDR in cancer: Addressing the underlying cellular alterations with the use of nanocarriers. Pharmacol Res. 2017;126:2-30.

4. Lapis K. Host defense peptides and peptidomimetics as new weapons for cancer treatment. Magy Onkol. 2010;54(1):47-58.

5. Bansal N, Amdani S, Lipshultz ER, Lipshultz SE. Chemotherapyinduced cardiotoxicity in children. Expert Opin Drug Metab Toxicol. 2017;13(8):817-832.

6. Ong ZY, Wiradharma N, Yang YY. Strategies employed in the design and optimization of synthetic antimicrobial peptide amphiphiles with enhanced therapeutic potentials. Adv Drug Deliv Rev. 2014;78: $28-45$.

7. Wang G, Li X, Wang Z. APD3: the antimicrobial peptide database as a tool for research and education. Nucleic Acids Res. 2016;44(D1): D1087-D1093.

8. Patel S, Akhtar N. Antimicrobial peptides (AMPs): The quintessential 'offense and defense' molecules are more than antimicrobials. Biomed Pharmacother. 2017;95:1276-1283.

9. Yan J, Wang K, Dang W, et al. Two hits are better than one: membraneactive and DNA binding-related double-action mechanism of NK-18, a novel antimicrobial peptide derived from mammalian NK-lysin. Antimicrob Agents Chemother. 2013;57(1):220-228.

10. Mansour SC, Pena OM, Hancock RE. Host defense peptides: front-line immunomodulators. Trends Immunol. 2014;35(9):443-450.

11. de La Fuente-Núñez C, Silva ON, Lu TK, Franco OL. Antimicrobial peptides: Role in human disease and potential as immunotherapies. Pharmacol Ther. 2017;178:132-140.

12. Lee $Y$, Phat C, Hong SC. Structural diversity of marine cyclic peptides and their molecular mechanisms for anticancer, antibacterial, antifungal, and other clinical applications. Peptides. 2017;95:94-105.

13. Yan JX, Wang KR, Chen R, et al. Membrane active antitumor activity of NK-18, a mammalian NK-lysin-derived cationic antimicrobial peptide. Biochimie. 2012;94(1):184-191.

14. Baxter AA, Lay FT, Poon IKH, Kvansakul M, Hulett MD. Tumor cell membrane-targeting cationic antimicrobial peptides: novel insights into mechanisms of action and therapeutic prospects. Cell Mol Life Sci. 2017;74(20):3809-3825.

15. Hoskin DW, Ramamoorthy A. Studies on anticancer activities of antimicrobial peptides. Biochim Biophys Acta. 2008;1778(2):357-375.

16. Otero-González AJ, Magalhães BS, Garcia-Villarino M, et al. Antimicrobial peptides from marine invertebrates as a new frontier for microbial infection control. FASEB J. 2010;24(5):1320-1334.

17. Augustin R, Anton-Erxleben F, Jungnickel S, et al. Activity of the novel peptide arminin against multiresistant human pathogens shows the considerable potential of phylogenetically ancient organisms as drug sources. Antimicrob Agents Chemother. 2009;53(12):5245-5250.

18. Fields GB, Noble RL. Solid phase peptide synthesis utilizing 9-fluorenylmethoxycarbonyl amino acids. Int J Pept Protein Res. 1990; 35(3):161-214.

19. Wender PA, Mitchell DJ, Pattabiraman K, Pelkey ET, Steinman L, Rothbard JB. The design, synthesis, and evaluation of molecules that enable or enhance cellular uptake: peptoid molecular transporters. Proc Natl Acad Sci US A. 2000;97(24):13003-13008.

20. Ferreira FR, da Silva PM, Soares T, et al. Evaluation of antimicrobial, cytotoxic, and hemolytic activities from venom of the spider Lasiodora sp. Toxicon. 2016;122:119-126.

21. Yan J, Liang X, Bai C, et al. NK-18, a promising antimicrobial peptide: anti-multidrug resistant leukemia cells and LPS neutralizing properties. Biochimie. 2018;147:143-152.

22. Ryan MA, Akinbi HT, Serrano AG, et al. Antimicrobial activity of native and synthetic surfactant protein B peptides. J Immunol. 2006; $176(1): 416-425$.
23. Hsu JC, Lin LC, Tzen JT, Chen JY. Characteristics of the antitumor activities in tumor cells and modulation of the inflammatory response in RAW264.7 cells of a novel antimicrobial peptide, chrysophsin-1, from the red sea bream (Chrysophrys major). Peptides. 2011;32(5): 900-910.

24. Yan J, Liang X, Liu C, et al. Influence of Proline Substitution on the Bioactivity of Mammalian-Derived Antimicrobial Peptide NK-2. Probiotics Antimicrob Proteins. 2018;10(1):118-127.

25. Rohl CA, Baldwin RL. Deciphering rules of helix stability in peptides. Methods Enzymol. 1998;295:1-26.

26. Srivastava S, Ghosh JK. Introduction of a lysine residue promotes aggregation of temporin $\mathrm{L}$ in lipopolysaccharides and augmentation of its antiendotoxin property. Antimicrob Agents Chemother. 2013;57(6): 2457-2466.

27. Eisenberg D, Mclachlan AD. Solvation energy in protein folding and binding. Nature. 1986;319(6050):199-203.

28. Gautier R, Douguet D, Antonny B, Drin G. HELIQUEST: a web server to screen sequences with specific alpha-helical properties. Bioinformatics. 2008;24(18):2101-2102.

29. Bandurska K, Berdowska A, Barczyńska-Felusiak R, Krupa P. Unique features of human cathelicidin LL-37. Biofactors. 2015;41(5): 289-300.

30. Nicoletti I, Migliorati G, Pagliacci MC, Grignani F, Riccardi C. A rapid and simple method for measuring thymocyte apoptosis by propidium iodide staining and flow cytometry. J Immunol Methods. 1991;139(2): 271-279.

31. Senchenkov A, Han TY, Wang H, et al. Enhanced ceramide generation and induction of apoptosis in human leukemia cells exposed to DT(388)-granulocyte-macrophage colony-stimulating factor (GM-CSF), a truncated diphtheria toxin fused to human GM-CSF. Blood. 2001;98(6):1927-1934.

32. Lage $H$. An overview of cancer multidrug resistance: a still unsolved problem. Cell Mol Life Sci. 2008;65(20):3145-3167.

33. Szakács G, Paterson JK, Ludwig JA, Booth-Genthe C, Gottesman MM. Targeting multidrug resistance in cancer. Nat Rev Drug Discov. 2006; $5(3): 219-234$

34. Banković J, Andrä J, Todorović N, et al. The elimination of P-glycoprotein over-expressing cancer cells by antimicrobial cationic peptide NK-2: the unique way of multi-drug resistance modulation. Exp Cell Res. 2013;319(7):1013-1027.

35. Utsugi T, Schroit AJ, Connor J, Bucana CD, Fidler IJ. Elevated expression of phosphatidylserine in the outer membrane leaflet of human tumor cells and recognition by activated human blood monocytes. Cancer Res. 1991;51(11):3062-3066.

36. Dobrzyńska I, Szachowicz-Petelska B, Sulkowski S, Figaszewski Z. Changes in electric charge and phospholipids composition in human colorectal cancer cells. Mol Cell Biochem. 2005;276(1-2):113-119.

37. Szachowicz-Petelska B, Dobrzyńska I, Skrodzka M, Darewicz B, Figaszewski ZA, Kudelski J. Phospholipid composition and electric charge in healthy and cancerous parts of human kidneys. J Membr Biol. 2013;246(5):421-425.

38. Wang KR, Yan JX, Zhang BZ, Song JJ, Jia PF, Wang R. Novel mode of action of polybia-MPI, a novel antimicrobial peptide, in multi-drug resistant leukemic cells. Cancer Lett. 2009;278(1):65-72.

39. Travkova OG, Moehwald H, Brezesinski G. The interaction of antimicrobial peptides with membranes. Adv Colloid Interface Sci. 2017; 247:521-532.

40. Bastos P, Trindade F, da Costa J, Ferreira R, Vitorino R. Human Antimicrobial Peptides in Bodily Fluids: Current Knowledge and Therapeutic Perspectives in the Postantibiotic Era. Med Res Rev. 2018;38(1): 101-146.

41. Parachin NS, Franco OL. New edge of antibiotic development: antimicrobial peptides and corresponding resistance. Front Microbiol. 2014;5:147. 


\section{Supplementary materials \\ Methods}

P-glycoprotein (P-gp) protein test by flow cytometry

The expression level of $\mathrm{P}$-gp is one of the parameters to consider whether it is a drug resistance or not in leukemic cells. ${ }^{1}$ To analyze the expression level of P-gp in K562 and K562/ ADM cells, flow cytometry was used before other studies.
K562 and K562/ADM cells were cultured as previously described. Then, the cells were harvested and incubated with the P-phycoerythrin (PE)-conjugated monoclonal antibody for surface expression of P-gp (Beckman Coulter, Inc., Brea, CA, USA) for 15 minutes. After that, cells were washed with PBS and analyzed using flow cytometry (Beckman Coulter).

Flow rate: $1.0 \mathrm{~mL} / \mathrm{min}$

Wavelength: $220 \mathrm{~nm}$

Volume: $10 \mu \mathrm{L}$

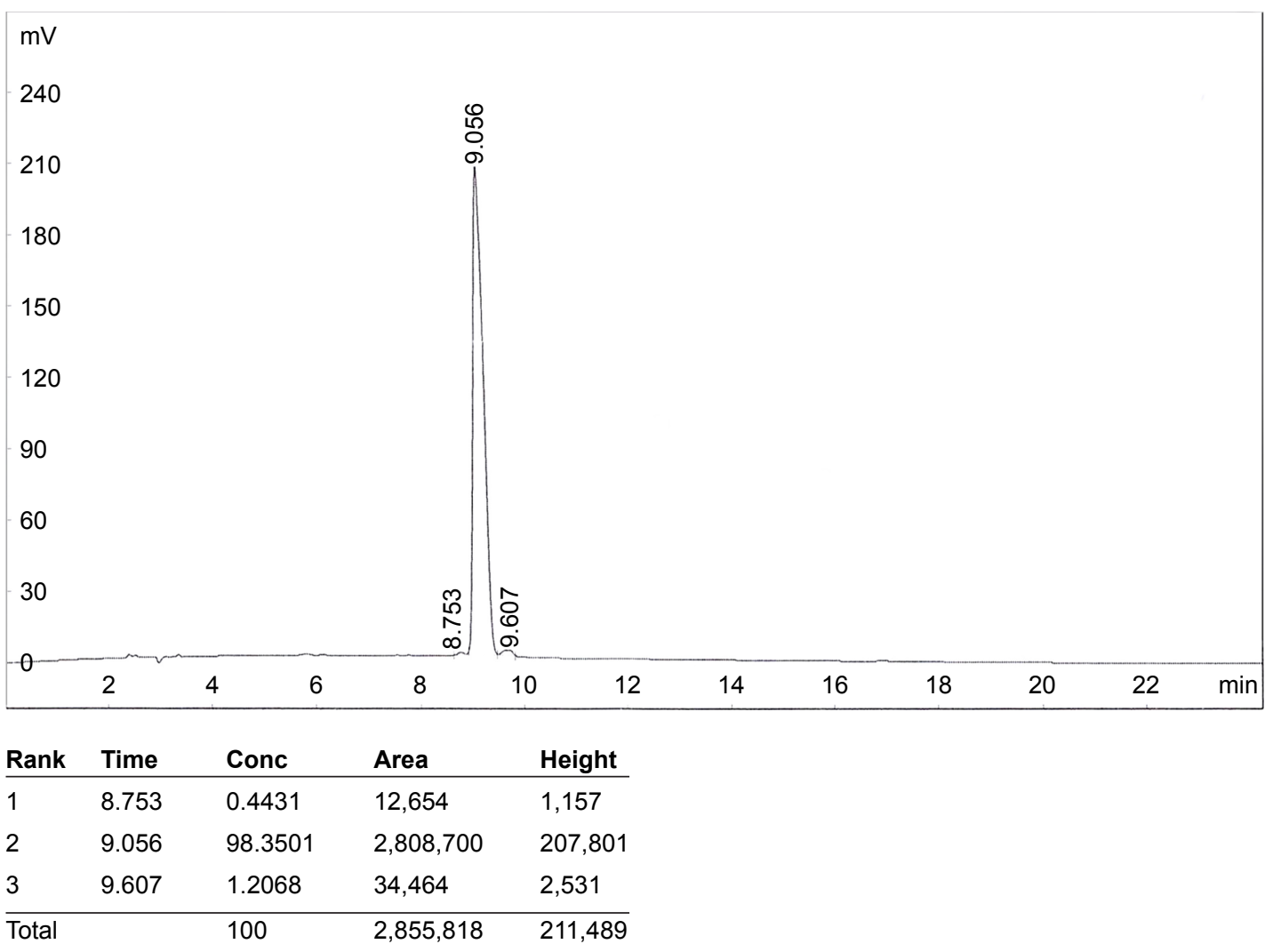

Figure SI The HPLC chromatogram of Arminin Ia-C.

Abbreviation: Conc, concentration. 


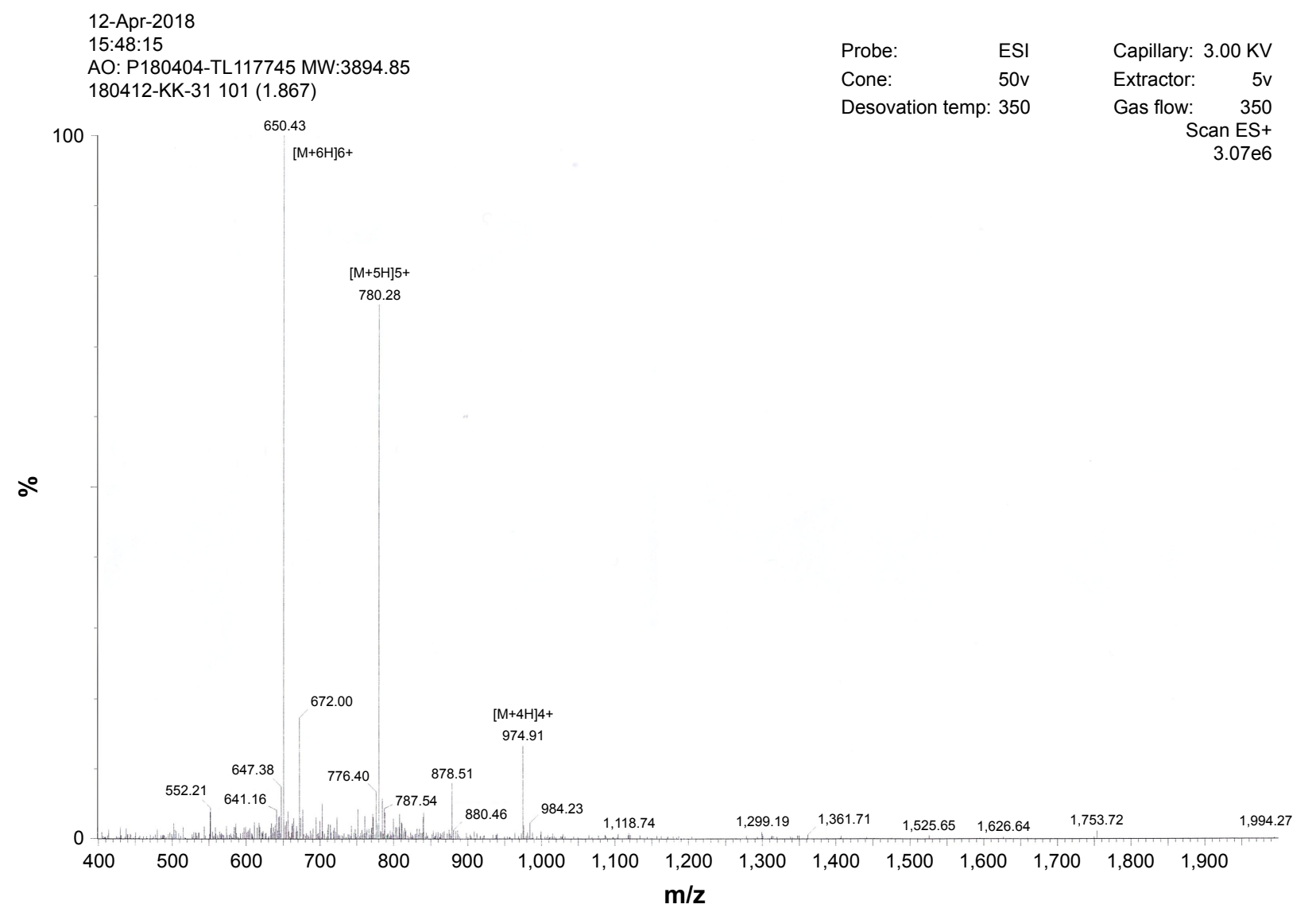

Figure S2 The MS of Arminin Ia-C.

Abbreviations: ESI, electrospray ionization; MS, mass spectrometry; MW, molecular weight.
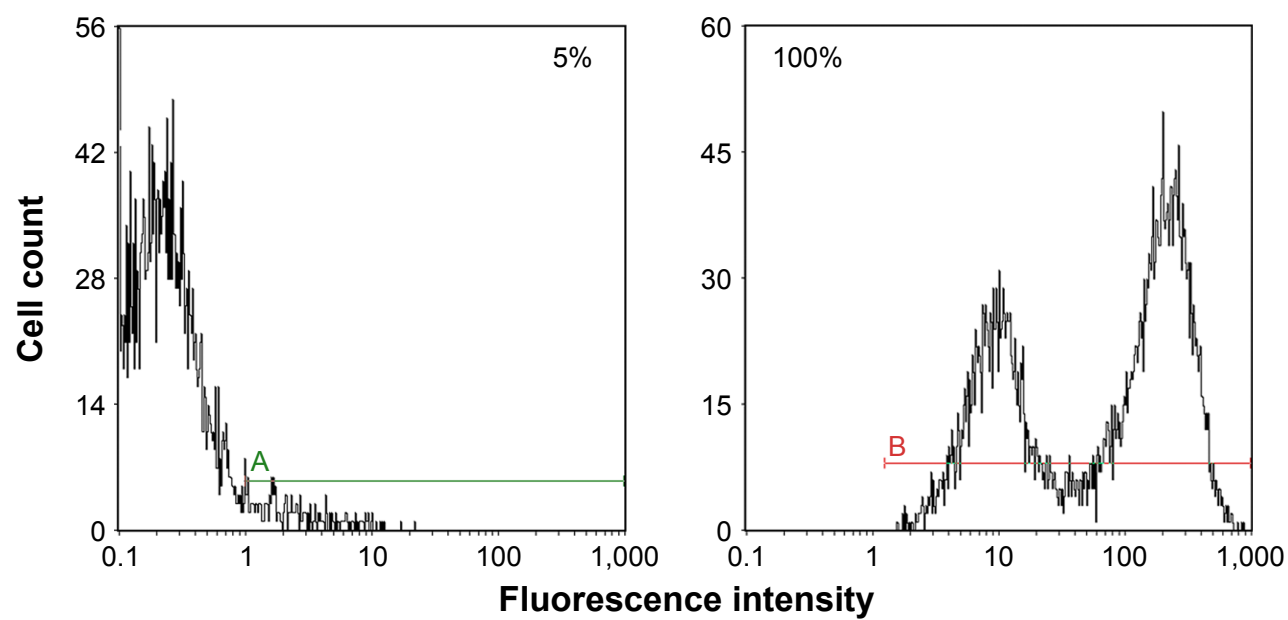

Figure S3 The P-gp expression in K562 and K562/ADM cells analyzed by flow cytometry.

Notes: Green A represents the percentage of positive fluorescence in K562 cells. Red B represents the percentage of positive fluorescence in K562/ADM cells. Abbreviations: ADM, adriamycin; P-gp, P-glycoprotein.

\section{Reference}

1. Vilas-Boas V, Silva R, Gaio AR, et al. P-glycoprotein activity in human Caucasian male lymphocytes does not follow its increased expression during aging. Cytometry Part A. 2011;79(11):912-919. 
Drug Design, Development and Therapy

Dovepress

\section{Publish your work in this journal}

Drug Design, Development and Therapy is an international, peerreviewed open-access journal that spans the spectrum of drug design and development through to clinical applications. Clinical outcomes, patient safety, and programs for the development and effective, safe, and sustained use of medicines are the features of the journal, which

has also been accepted for indexing on PubMed Central. The manuscript management system is completely online and includes a very quick and fair peer-review system, which is all easy to use. Visit http://www.dovepress.com/testimonials.php to read real quotes from published authors.

Submit your manuscript here: http://www.dovepress.com/drug-design-development-and-therapy-journal 